\title{
BALTIC SOCIAL JUSTICE SCHOOL LEADERS
}

\author{
Jenny S. Tripses', Ilze Ivanova², Jūratė Valuckiené ${ }^{3}$, \\ Milda Damkuviené ${ }^{3}$, Karmen Trasberg ${ }^{4}$ \\ ${ }^{1}$ Bradley University, Peoria, Illinois USA \\ 2 University of Latvia, Riga, Latvia \\ ${ }^{3}$ Vilnius University Šiauliai Academy \\ ${ }^{4}$ Tartu University, Tartu, Estonia
}

\begin{abstract}
Social justice school leadership as a concept, while familiar in the United Kingdom, Australia, New Zealand, Canada, and the United States school leadership literature, is not widely recognized in other parts of the world. Social justice school leadership appropriately differs from one culture to another and is always context-specific to a particular school setting, great organization structure or country. However, social justice is a necessary and fundamental assumption for all educators committed to combating ignorance and the promotion of student global citizenship as a central theme of school practices. The purpose of this study was to provide understandings of ways that selected social justice school leaders from three countries; Lithuania, Latvia, and Estonia conceive of and practice social justice in leading their schools.

The manuscript describes how six Baltic directors, identified by local educators on the basis of research conducted by the International School Leaders Development Network (ISLDN) as social justice school leaders, responded to interview questions related to their practice. Four directors were Latvian and one each from Lithuania and Estonia. Limitations to the study include basing conclusions upon a single (or in one case, several) interview(s) per subject and limitations on generalizability of qualitative exploratory case study. By definition, every case study is unique, limiting generalizability.

Interviews were thematically analyzed using the following definition: A social justice school leader is one who sees injustice in ways that others do not, and has the moral purpose, skills, and necessary relationships to combat injustice for the benefit of all students. Findings reveal strong application of values to identify problems based on well-being of all students and their families and to work collaboratively with other educators to find solution processes to complex issues related to social justice inequities. As social justice pioneers in their countries, these principals personify social justice school leadership in countries where the term social justice is not part of scholarly discourse.
\end{abstract}

Keywords: democratic leadership, leadership values, moral leadership, qualitative case study, problem solving, social justice school leaders. 


\section{Introduction}

The results of the study reported here relate stories of educational leaders from countries (Estonia, Latvia, Lithuania) where the term social justice is not part of educational discourse. None of the school leaders involved in the study, on the other hand, struggled to understand concepts related to identifying and resolving issues when students failed to learn. School leaders throughout the world have moral and political responsibilities to educate others into opportunities to better their lives (Bogatch, 2014). Education throughout the world promotes the welfare of civil society. Social justice, irrespective of whether or not practicing school leaders are familiar with the term, is defined by participants, in this case Baltic school leaders, and then validated by researchers (Bogatch, 2014).

This manuscript seeks to provide understandings of ways that social justice school leaders from three countries; Lithuania, Latvia, and Estonia conceive of and practice social justice in leading their schools. Findings are based upon interview research conducted in the spring 2018 through fall 2019. Interview data were analyzed and reported based upon one author's definition of social justice.

There are multiple definitions of social justice school leaders. The International School Leaders Development Network (ISLDN) defines a social justice school leader as a "principal (called director in Baltic countries) who is committed to reducing inequalities and makes this aim a high priority in leadership practice" (Angelle, 2017, p. 308). Muzaliwa \& Gardiner, 2014 define social justice school leaders as "agents who are called to initiate change in classrooms, school buildings, and communities toward equity and inclusion." This manuscript analyzes and reports on Baltic social justice school leaders on the basis of this definition: "A social justice school leader is one who sees injustice in ways that others do not, and has the moral purpose, skill, and necessary relationships to combat injustice for the benefit of all students" (Tripses, 2021). The specific research question was "How do these six Baltic social justice school leaders describe ways they perceive and address injustice, act upon the basis of moral purpose, employ skills in their leadership role, and develop and maintain relationships with the intent to benefit all students?"

Social justice school leadership appropriately differs from one culture to another. As countries are called to deal with complex changes due to globalization, each of the 190 nations in the world is challenged to redefine educational quality for its citizens (Bogotch, 2014). "One cannot even begin to develop an educational system unless one has in mind the knowledge and skills that one values, and the kind of individuals one hopes to emerge at the end of the day" (Gardner, 2008, p. 14). 
“Social justice cannot fall outside an educator's professional agenda or even reside at the margins; rather social justice is a necessary and fundamental assumption for all educators committed to combating ignorance and becoming more informed global citizens (Bogotch \& Shields, 2014). Recognizing that social justice is always context-specific to a particular school setting, great organization structure or country, this research project sought to deepen understanding of ways social justice is defined, utilized, and enacted in Lithuania, Latvia, and Estonia.

\section{Conceptual Design - Social Justice School Leadership and Moral Purpose}

The conceptual framework is grounded in a review of the literature on social justice school leadership, focusing specifically upon moral purpose. Connections between social justice school leadership and moral purpose in leadership are frequently drawn. Moral purpose is the foundation for all other social justice school leadership actions (Fullan, 2020, Sergiovanni, 1992, 1999). Moral purpose, when articulated in word or actions, appeals to the innate sense held by some (or many) individuals of what is right and what is worthwhile.

Moral purpose in school leadership is concerned with right and wrong (Furman, 2003), maintains a strong focus on the common good (Fullan, 2003), the development a common sense of purpose (Fullan, 2003; Furman, 2003; Sergiovanni, 1992, 1999) and the development of leadership potential in others (Fullan, 2003). Leaders with a strong moral purpose have the capacity to see beyond constraints in the environment that stem from bureaucratic policies, scarce resources, oppression, and societal issues reflected in the lives of students and their families (Lyman, Ashby, \& Tripses, 2005; Tripses, 2019).

The essence of moral purpose is principled behavior connected to something greater than ourselves that relates to human and social development. Furman (2003) stated "Moral purpose is the focus of leadership studies as it ought to be, not just the ethics and values of leaders themselves, but how these values get translated into institutional change" (p. 1). Furman is referring to ways leadership works when confronting novel and difficult problems. Moral purpose requires actions by the leader and others that go far beyond compliance towards bureaucratic rules or authorities. Moral purpose involves leaders to thoughtfully consider the value, meaning, and purpose of schooling that results in subsequent actions to meet increasingly diverse and complex challenges in pluralistic societies (Lyman, Ashby, \& Tripses, 2005; Tripses, 2019).

School leader's responsibility, whether their practice could be described as social justice leadership or not, always involves discretion related to 
decisions in terms of how to handle (or not handle) a situation involving a need presented by a student or family whose requirements for learning don't fit neatly into the available program or way of doing things (Sergiovanni, 1999). School leaders who overlook conditions that impede some students' progress in school adopt positions used to justify status quo actions by educators towards a particular group or individual student. Explanations that blame the victim such as the student is lazy or that families don't care about them are just that, excuses. School leaders who persist in questioning the status quo and work with others to overcome negative consequences for students whose needs don't fit neatly into the regular school treatment are bucking the system. Such directors are social justice school leaders.

Social justice school leadership requires intention, skill, and constant attention. "Leadership for social justice investigates and poses solutions for issues that generate and reproduce societal inequities" (Dantley \& Tillman, p. 20, 2010). Given the complexity and specificity of ways that societal inequities come into being and persist over time, actions must always be situation specific created through local problem analysis. Collective action to redress inequities and analysis designed to determine effectiveness of the application intended to create greater equity complete the cycle.

There is another aspect to social justice school leadership. All schools are bureaucratic in some form or another designed to educate a maximum number of students according to the cultural norms and history of a particular society. In the vast majority of cases the remedy which is the sum of what is called "education" adheres in some form or another to fixed division of labor, hierarchies, set of rules governing performance (Bolman \& Deal, 2013). The issues that students and their families present at school can and often do, fail to fit neatly into the treatments prescribed by which a particular school bureaucracy is designed. The causes for the mismatch can stem from issues related to societal oppression, changing conditions that bring students with learning needs unfamiliar to the school bureaucracy such as an influx of immigrants into a community, or as happened in the 2020 pandemic when schools worldwide faced conditions where face to face school was considered unsafe for students and teachers.

Moral leadership or purpose expressed through values requires motivation beyond compliance towards bureaucratic rules or authorities (Tripses, 1998). Begley (1999) defines values as "those conceptions of the desirable which motivate individuals and collective groups to act in particular ways to achieve particular ends" (p. 237). Rokeach (1973, explains that a person's value system is a learned set of rules for making choices and for resolving conflicts (as cited in Leithwood \& Steinbach,1995). Social justice school leaders develop the capacity to conceptualize and articulate 
leadership that incorporates democratic community engagement, spirituality, emotion, caring, and connection. Over time, social justice school leaders develop congruence between values and practice, moving beyond philosophical rhetoric into more realistic hard-won social justice practice.

\section{Method}

The research followed the prescribed International School Leaders Development Network ISLDN protocols to learn more about how social justice leaders make sense of 'social justice', how they do social justice leadership, factors that help and hinder the social justice leadership work, and finally how they learn to become social justice leaders (International School Leadership Development Network isldn.weebly.com). Collaboration with local university scholars in all three Baltic countries who were familiar with local schools was essential in order to conduct an interview following the prescribed ISLDN research protocols. The collaborative colleague identified an appropriate local school leader(s) using the "snowball technique" of participant identification, helped conduct the interview as needed, and assisted with the post-interview write up. Subjects were all employed as school leaders. Higher education background of the directors was not asked in the interview, but subjects volunteered that none received higher education preparation in school leadership. Four of the six began their careers as teachers and from there moved to school leadership. Two began in other careers (accounting and physics) and moved to school leadership later in their careers. All directors in the study had at least three years' experience in their school.

All subjects received a copy of the interview questions as well as a brief explanation of the research, in advance as part of the consent to participate process. A summary organized around ISLDN interview questions was sent to each subject and any colleagues who attended the interview to member check that the summary was an accurate representation of their stories (Creswell \& Creswell, 2018). The analysis presented here is based upon interview transcripts, interview and field notes (Miles, Huberman, \& Salada, 2020).

\section{Limitations}

Limitations to this study include basing conclusions upon a single (or in one case, several) interview(s) per subject and limitations on generalizability of qualitative exploratory case study in general (Creswell and Creswell, 2018, Yin, 2009). By definition, every case study is unique, limiting generalizability. 
Broad themes were identified from the initial interviews and those themes were analyzed (Miles, Huberman \& Saldana, 2020) around ways subjects viewed social justice, practice based upon moral purpose, necessary skills, relationships with others, and focus on the well-being of all student (Bolman and Deal 2017; Fullan, 2020).

One author (American) was in Latvia as a Fulbright Scholar in the spring 2018 on a teaching/research grant on social justice school leaders. Her connections with ISLDN and social justice scholarship contributed to the project. The remaining authors (one Latvian, two Lithuanian and one Estonian) helped organize the interviews with the identified social justice school director, and reviewed the summary of the interview provided by Tripses. Each co-author contributed significantly to the validity of the interviews by providing additional insights into the culture of a particular school and/or the national educational organization. The two Lithuanian co-authors translated and transcribed the interview which was conducted in Lithuanian. Both co-authors were involved in the final analyses and writing of the Lithuanian Director's interview.

\section{Results}

The six directors and their schools varied significantly. One school was in a rural area, two were located in a large urban city (population 692,000), one in a university town (population 100,00), and two in towns outside of Riga, Latvia. Four schools were Latvian and one each Lithuanian and Estonian. Two of the schools were private and in each of these cases, the director interviewed was the only school leader since the school's inception. The director's tenure at their present school ranged from three years to twenty-eight years. Three schools served students in grade school, one was a gymnasium for high school students intending to go to university and the other high school was a technical school where approximately half the students planned to go on to university. One school served students from preschool to high school. Four of the directors were trained as educators in university and two began in other fields (accounting and physics). The two who switched careers to school leadership later returned to university for advanced degrees in pedagogy. Two directors worked for a time in their county's ministry of education. Directors volunteered their age (they weren't asked) so it is known that their ages ranged from 37 to 77 at the time of the interview, significant given that this group represents a population of school leaders who experienced "Soviet times" and independence at different points in their lives.

The specific research question upon which this manuscript is based was "How do these six Baltic social justice school leaders describe ways they 
perceive and address injustice, act upon the basis of moral purpose, employ skills in their leadership role, and develop and maintain relationships with the intent to benefit all students?"

All six directors were unanimous in describing injustice as situations that required all educators on site to problem solve for solutions. None were familiar with the term social justice, but each readily understood the concepts. Their descriptions of social justice included democratic leadership (2), inclusion (1), and development of the whole child in order to become confident in their abilities to use their strong academic skills (3). In the words of one director, "Education in a democratic society should be based on learning to find common agreements and living in such an environment." The directors interviewed were very clear about the need in their schools to engage others to find common solutions presented by students whose needs extend beyond the traditional program. Put another way, another director stated "I'm very sensitive towards any injustice towards children. I think adults have to be there for the children and protect them."

Leadership actions based upon moral purpose focused heavily on meeting the child's needs. The concept of unconditional acceptance of each child was frequently mentioned as a starting place for educators to begin the process of schooling. Another frequent theme was director's insistence that teachers, other educators, and in some cases, parents, problem solve together to find solutions for individual students. "We don't hide our problems, but rather solve them together" said one director. Students were also frequently involved in problem solving, sometimes through educator-created situations and other times as problems arose. Five of the six directors explicitly stated their conception of their leadership role was to intentionally teach students to problem-solve.

The leadership skills described by these directors all involved engaging others in decisions. Explanations for policy decisions that come from the ministries of education were cited (especially by the two directors with experience in ministries of education at the national level) as critical in order for teachers to understand their roles. Such conversations are heavily dependent upon the director's understanding of the issues and how they can be implemented locally. While each subject talked about working with teachers to resolve problems, one director talked specifically about the need to create and nurture the expectation that all teachers in the school support one another to work towards the common goals based upon student needs. One director stated, "I find democracy very important in education ... democracy means more principles, more values ... . We give considerable attention to working out collective agreements, even though they are often not very convenient for adults. ... That's direct democracy; I like such things." 
Relationships with students, teachers, parents, and the community at large were central to director responses related to their social justice leadership. When asked about what they regard as challenges related to social justice leadership, several directors talked about teachers who resisted efforts to meet the needs of all students. All but one director spoke of these challenges in the past tense and the one who indicated teacher resistance remained had only three years at the school. The previous director was in the position for over twenty years and had been very traditional in his practice. Some teachers at this school preferred traditional roles and failed to appreciate the need for time to work with other teachers on decision making processes. They preferred more traditional top-down decision-making processes. But this director stated confidently that these attitudes were shifting, however slowly. All directors talked about the importance of working with their leadership team whether that involved all teachers in smaller schools or several deputy directors in schools with larger enrollments. The difficulty of the work was described by one director, "I see teachers come. They become (name of school) teachers or leave in a year or two." Another put it this way, "Social justice requires great patience. ... You can't feed every child in the morning, but you must take care of that (if a child arrives hungry)."

\section{Discussion}

Despite broad diversity based upon nationality, size and type of school, and professional backgrounds of the social justice school leaders interviewed for this project, their responses indicate far more similarity than differences. Each comfortably described deep convictions related to providing equitable education to all students. Words used to describe values that inspire leadership actions, varied some, but intent was similar. Each demonstrated deep respect for other educators in the schools even when describing differences of opinion. Problems, whether they were changing demographics, historical factors, differing concepts related to pedagogical approaches, were described more as interesting puzzles than insurmountable obstacles.

This prevailing attitude on the part of the directors affirms problem-solving expertise as described by Leithwood and Steinbach (1995). In their study, American superintendents determined to be expert problem-solvers as compared to other school leaders, approached ill-structured problems by devoting more time to interpret the problem before attempting to a resolution stage. The six directors' descriptions of causes of social injustice were clearly articulated in the interviews. But included in their narratives was another characteristic of Leithwood \& Steinbach's expert problem solvers. 
These directors recognized and had strategies to deal with the constraints. Demonstrating another aspect of the definition of social justice school leaders used in this report, these directors described processes used to take problems to other educators or in some instances to students, parents, or community leaders, for resolution. Another characteristic of expert problem solvers involved basing solutions upon values, which are closely related to what is termed in leadership literature as moral leadership, discussed earlier in this manuscript. Leithwood \& Steinbach reported (1995) that expert problem solvers are more aware of their values, use values more frequently in problem-solving, and use values as substitutes for knowledge when solving ill-structured problems. The final characteristic cited by Leithwood \& Steinbach (1995), involves mood or confidence in their abilities to work with others to create solutions. Research notes affirm that each director exhibited confidence in outcomes when addressing ill-structured problems related to social justice school leadership.

The subjects in this study were aware of bureaucratic structures in their country's ministry of education that create complications arising when student needs do not match programmatic doctrines. The most prevalent obstacle resolved around funding for rural or country schools which is not always deemed adequate. These inequities did not affect all schools equally. Those directors whose schools were affected described the remedies as local problems for the educators and community leaders to resolve.

Recommendations from the United States used as part of school leader preparation include the use of equity audits (Furman, 2012; Skrla, Scheurich, Garcia, \& Nolly, 2010), intentional instruction into the development of moral purpose in school leadership and most notably, experiences from Baltic school leaders who lead their schools from strong social justice perspectives. "Capacity building for social justice leaders requires a blending of theory, research, reflections on practice, tools for teaching and other interventions, strategies for engaging passion and emotion, and finally realistic engagement in real-world policy and practice" (Marshall \& Olivia, p. 12, 2010).

\section{Conclusions}

Social justice school leadership distinctly appeared in the interviews with the six Baltic directors using methods guidelines by ISLDN. Directors were focused on purpose of schooling, employing values or moral purpose in their leadership, working respectfully with other educators to resolve issues related to inequities, and strong pedagogical skills.

Further study is indicated into school leader preparation in the three Baltic countries to better understand the development of strong social 
justice school leaders. More inquiry is needed into what directors meant about democratic methods as a means to enact social justice in their schools. Every country needs more school leaders like one of the directors interviewed who decided become a director of a small rural school in order to "break the myth that education in the rural territories is condemned." He sought to dispel the notion that family socioeconomic status creates situations that schools are powerless to overcome.

The hope is that as deeper understandings of Baltic social justice school leadership practices, preparation and support for practicing school leaders will create more school leaders willing and able to confront myths about students who fail to reach their potential in schools. The stories of these school directors clearly demonstrate strong social justice school leadership.

Returning to what was stated at the beginning of this manuscript school leaders from each country define social justice school leadership in their countries. The subjects of this study have fully accepted that responsibility.

\section{Acknowledgement}

Research for this chapter was sponsored through a Fulbright Scholar grant through US Department of State grant in partnership with the University of Latvia. Correspondence concerning this manuscript should be addressed to Jenny S. Tripses at jtripses@fsmail.bradley.edu

\section{References}

Angelle, P. (2017). Moving forward. In: Angelle (Ed) A Global Perspective of Social Justice Leadership for School Principals. P. 303-319. Information Age Publishing.

Begley, P. (1999). Value preferences, ethics, and conflicts in school administration. In P. Begley (Ed.), Values and Educational Leadership (pp. 237-254). State University of New York Press.

Bogatch and Shields (2014). Do promises of social justice trump paradigms of educational leadership? (Vol. 1). In Bogatch \& Schields (Ed.) International Handbook of Educational Leadership and Social (In) Justice (pp. 1-12). Springer Press.

Bogatch, I. (2014). Educational theory: The specific case of social justice as an educational leadership construct (Vol. 1). In Bogatch and Shields (Ed.) International Handbook of Educational Leadership and Social (In) Justice (pp. 51-66.) Springer Press

Bolman, L. \& Deal, T.. (2017) Reframing organizations, $6^{\text {th }}$ Ed. Jossey-Bass.

Bolman, L, \& Deal, T. (2013). Reframing Organizations: Artistry, Choice, and Leadership. Jossey-Bass.

Creswell, J. \& Creswell, D. (2018). Research Design: Qualitative, Quantitative, and Mixed Methods Approaches. Sage Publications.

Dantley, M. \& Tillman, L. (2010). Social justice and moral transformative leadership. In C. Marshall \& M. Oliva (Eds), Leadership for Social Justice $2^{\text {nd }}$ Ed. (pp. 19-34). Pearson. 
Fullan, M. (2003). The Moral Imperative of School Leadership. Thousand Oaks, CA: Corwin Press.

Fullan, M. (2020). Leading in a Culture of Change, $2^{\text {nd }}$ ed. Jossey-Bass Publishers.

Furman, G. (2003). The 2003 UCEA presidential address. UCEA Journal, Winter 2003, Volume XLV, No. 1.

Furman, G. (2012). Social justice leadership as praxis: Developing capacities through preparation programs. Educational Administration Quarterly, 48(2), 191-229.

Gardner, H. (2008). Five Minds for the Future. Harvard Business Press.

Leithwood, K., \& Steinbach, R. (1995). Expert Problem Solving: Evidence from School and District Leaders. State University of New York Press.

Lyman, L. L, Ashby, D. E, \& Tripses, J. S. (2005). Leaders Who Dare: Pushing the Boundaries. Rowman \& Littlefield Education.

Marshall, C. \& Olvia, M. (2010). Building capacities of social justice leaders. Marshall \& Oliva (Eds). In Leadership for Social Justice ( $2^{\text {nd }}$ Ed). Allyn \& Bacon.

Miles, Huberman, Saldaa. (2020). Qualitative Data Analysis: A Methods Sourcebook, $\left(4^{\text {th }}\right.$ Ed). Sage Publications.

Muzaliwa, A. I.-I., \& Gardiner, M. E. (2014). Narrative inquiry as an exemplary method for social justice leadership Vol. 1). In I. Bogotch \& C. M. Shields (Eds.) International Handbook of Education Leadership and Social [In]Justice. Springer.

Shields C.M., Bogotch I. (2014) The Way Forward. (Vol. 2). In: Bogotch I., Shields C. (Eds) International Handbook of Educational Leadership and Social (In) Justice. Springer, Dordrecht.

Sergiovanni, T. (1992). Moral leadership: Getting to the heart of school improvement Jossey-Bass Publishers.

Sergiovanni, T. (1999). Rethinking leadership. Skylight Training and Publishing, Inc.

Skrla, L., Scheurich, J., Garcia, J., Nolly, G. Equity audits: A practical leadership tool for developing equitable and excellent schools. In C. Marshall \& M. Oliva (Eds), Leadership for Social Justice $2^{\text {nd }}$ Edition (pp. 259-283). Pearson.

Tripses, J. S. (1998). An examination of the principal's role in managing the paradox of state mandated school improvement and accountability, Planning and Changing, 29(4), 214-236.

Tripses, J. (May 2019). Our future is in our minds and hearts. ICPEA International Journal of Educational Leadership Preparation, Vol. 14, No. 1, Spring 2019. ISSN $1532-0723$.

Tripses J. S. (2021) Moral Purpose Expressed Through Values by Social Justice School Leaders in the Baltic. In: Mullen C.A. (Ed) Handbook of Social Justice Interventions in Education. Springer International Handbooks of Education. Springer, Cham. https://doi. org/10.1007/978-3-030-29553-0_85-1.

Yin, R. K. (2009). Applications of case study research. Sage. 